\title{
pombalina
}

(8)

\section{Hermenêutica: questão de método ou filosofia prática?}

Autor(es): $\quad$ Portocarrero, Maria Luísa

Publicado por: Imprensa da Universidade de Coimbra

URL

persistente: URI:http://hdl.handle.net/10316.2/32236

DOI: $\quad$ DOI:http://dx.doi.org/10.14195/978-989-26-0361-2_8

Accessed : $\quad$ 26-Apr-2023 10:35:31

A navegação consulta e descarregamento dos títulos inseridos nas Bibliotecas Digitais UC Digitalis, UC Pombalina e UC Impactum, pressupõem a aceitação plena e sem reservas dos Termos e Condições de Uso destas Bibliotecas Digitais, disponíveis em https://digitalis.uc.pt/pt-pt/termos.

Conforme exposto nos referidos Termos e Condições de Uso, o descarregamento de títulos de acesso restrito requer uma licença válida de autorização devendo o utilizador aceder ao(s) documento(s) a partir de um endereço de IP da instituição detentora da supramencionada licença.

Ao utilizador é apenas permitido o descarregamento para uso pessoal, pelo que o emprego do(s) título(s) descarregado(s) para outro fim, designadamente comercial, carece de autorização do respetivo autor ou editor da obra.

Na medida em que todas as obras da UC Digitalis se encontram protegidas pelo Código do Direito de Autor e Direitos Conexos e demais legislação aplicável, toda a cópia, parcial ou total, deste documento, nos casos em que é legalmente admitida, deverá conter ou fazer-se acompanhar por este aviso. 
Diogo Ferrer

Coordenação

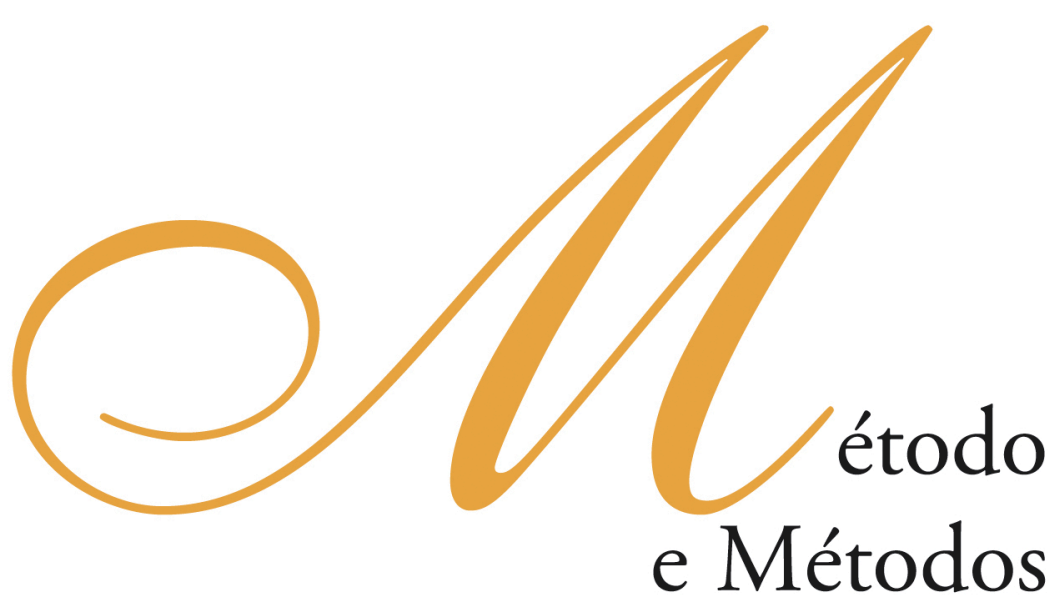

do Pensamento Filosófico 


\section{COORDENAÇÃO EDITORIAL \\ Imprensa da Universidade de Coimbra}

URL: http//www.imp.uc.pt

\section{CONCEPÇÃO GRÁFICA}

António Barros

PRÉ-IMPRESSÃO

Victor Hugo Fernandes

EXECUÇÃO GRÁFICA

Inova - Artes gráficas

ISBN

989-8074-02-7

DEPÓSITO LEGAL

$257236 / 07$

(C) Março 2007, Imprensa da Universidade de Coimbra

OBRA PUBLICADA COM O APOIO DE:

Centro de Estudos Clássicos e Humanísticos

FCT Fundação para a Ciência e a Tecnologia MINISTÉRIO DA CIÊNCIA E DA TECNOLOGIA 
Diogo Ferrer

Coordenação

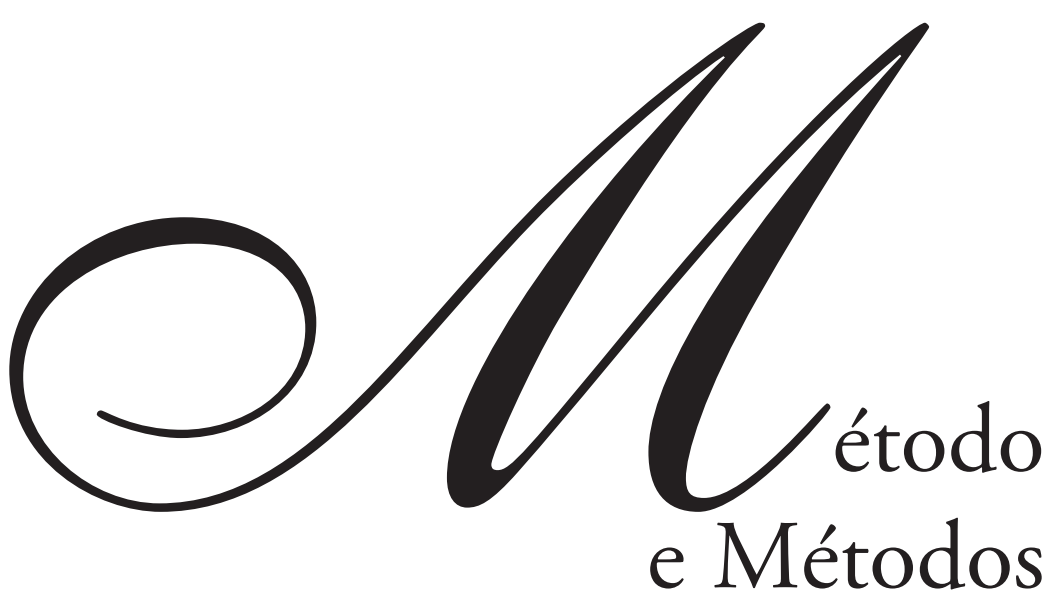

do Pensamento Filosófico

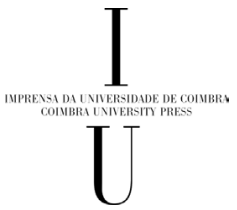

- COIMBRA 2007 



\section{Maria Luísa Portocarrero}

\section{Universidade de Coimbra}

\section{HermenêUtica: Questão de método ou filosofia PRÁtica?}

Se, de facto, foi como método científico que a Hermenêutica adquiriu pela primeira vez um estatuto filosófico, não é a questão estritamente metodológica aquela que define a sua temática crucial. Pelo contrário, a problemática hermenêutica tem na sua raiz uma questão ética, é suscitada pela dimensão simbólica da linguagem, isto é, pelo facto de a palavra que nos chega e suscita a interpretação nunca ser uma simples notação objectiva de algo, mas antes o resultado da implicação de pessoas em coisas e em relações com os outros logo, um índice de sentidos vividos, de decisões, de atitudes e de valores $(1)$.

É esta a tese que vou aqui sustentar, baseada em Gadamer, embora saiba que a Hermenêutica se torna pela primeira vez filosófica com Fr. Schleiermacher, filósofo romântico e teólogo protestante e com W. Dilthey, o criador da autonomia científica do mundo do espírito. Para os dois filósofos a Hermenêutica era motivada pela questão da alteridade pessoal e pela da sua inteligibilidade; era uma forma de conhecimento ou por outras palavras, o método de acesso à forma de vida absolutamente singular que é o humano. Os dois hermeneutas partilham, de facto, uma preocupação comum: compreender, respeitando-o, o carácter inefável da vida humana, enquanto realidade descoberta pelo Romantismo e pelas filosofias da vida

(1) Cf., neste sentido, G.Gusdorf, La parole, Paris, Puf, / Quadrige, 1998. pp. 12-36. 
como aquilo que escapa à objectividade do modelo explicativo. A vida não pode entender-se directamente, esta era a grande novidade da época: a visão, a reflexão e a representação não captam os seus testemunhos de modo adequado, pelo que ela apenas pode compreender-se por meio da relação meditativa entre texto, significação e interpretação. A vida é uma forma personalizada de alteridade que recusa qualquer redução à categoria da coisa inerte; tal é o pressuposto desta concepção: ser pessoa é ser vida que se faz significação, o que exige um modo de apreensão que respeite a natureza intencional, comunicativa desta nova realidade. O modelo explicativo próprio da apreensão metódica moderna da natureza revela-se aqui inadequado, uma vez que se baseia na estrutura visual clássica da representação, que apenas compreende realidades inertes (coisas), por meio da aplicação a tais realidades das categorias mentais que nelas permitem estabelecer relações causais.

Ora, a vida ultrapassa a textura meramente estática da representação, é dinamismo que misteriosamente se transforma em projecto, mediante a irrupção de estruturas comunicativas e simbólicas que iniciam uma nova ordem na realidade: aquela que é marcada pelo aparecimento da ética, da linguagem, da justiça e da história, fenómenos que inauguram o reino do sentido, que alimentam o radical questionamento dos seres humanos e exigem partilha.

Na opinião de Fr. Schleiermacher, o interesse do intérprete pelos sinais do outro é tal que aquele tem até o poder de compreender melhor o autor de um texto do que ele próprio; também para Dilthey a compreensão deve reproduzir o sentido primeiro do texto, o projecto real do seu autor, refazendo a ordem do vivido.

Tais são, de forma muito breve, os termos da questão hermenêutica nos finais do séc. XIX, século que substitui a universalidade da linguagem matemática, da moderna ciência, pela particularidade das línguas, das épocas e das nacionalidades. Percebe-se que o mundo da vida deve ser pensado e descoberto para além das abstracções científicas; que é o mundo da cultura, 
das diferentes tradições e das relações humanas, um mundo marcado pela história, pela alteridade, pela transmissão e pela memória. O mundo vivido é, em suma, urdido pelas significações que recusam o modelo visual e explicativo de mediação e exigem uma psicologia hermenêutica capaz de efectuar o percurso que vai da significação até ao mistério da existência que lhe subjaz.

Dilthey sustentou, no seu texto de 1900 sobre a emergência da hermenêutica e até aos seus últimos trabalhos, que o quadro conceptual no interior do qual ele próprio procurava fundar as ciências humanas era o da psicologia. Os problemas hermenêuticos situavam-se para si no interior de uma psicologia(2) descritiva e analítica, que precisava de se afirmar como ciência autónoma, mediante um método sólido capaz de permitir objectividade e um estatuto digno para as ciências do espírito.

Compreende-se o bomem, explica-se a natureza, tal é a célebre máxima com que o filósofo consagra, na altura, o carácter estritamente metodológico da hermenêutica; limitada a puro método, aquele que salvaguarda a autonomia das ciências históricas ou do espírito, a hermenêutica estabelecia as regras de leitura e compreensão dos grandes monumentos da cultura ocidental, percebendo que na raiz da obra cultural está a noção de texto e não a da simples imagem. Nesta altura, no entanto, não era possível a Dilthey explorar todas as importantes implicações desta diferença, pois, a sua grande preocupação era a objectividade das ciências humanas. Ocupouse então com as manifestações significativas da vida histórica, que tinham a intencionalidade do texto, percebendo ao mesmo tempo que a palavra constitui o núcleo fundamental das relações humanas; que o mundo humano não é um mundo de sensações e reacções eficientes, mas pelo contrário um mundo de ideias e designações, em que importa absolutamente participar;

(2) H. G. Gadamer, Gesammelte Werke X. Hermeneutik im Rücblick, Tübingen Mohr, 1995 , p. 188. 
e que o texto resume um modo de ver mundo a partir de uma situação particular.

Entender de um outro modo a realidade, apreendê-la com o outro, «cum -preendere», tal é o motivo da conversão hermenêutica do filosofar, que assim surge como uma outra via da racionalidade, aquela que acredita que sem a comunicação e a memória não há caminho de meditação possível. Digamos pois que a hermenêutica filosófica responde a uma crise do filosofar, cujo método era o monólogo do cogito soberano, e propõe-se, embora ainda sob a forma epistemológica, como o lugar de uma necessária reavaliação da racionalidade. A atenção agora centrada no carácter singular do mundo do espírito e no da sua compreensão, por meio do texto, transforma o tradicional modelo da exegese dos grandes clássicos, que orientavam de forma ética e jurídica as comunidades humanas, num modelo do pensar. Toma-se consciência, através da crise das tentativas de sistematização do histórico, de que o ideal de rigor e objectividade, criador do universal das ciências da natureza, não pode aplicar-se às Humanidades. Nem tão pouco pode aceitar-se sem uma prévia reflexão sobre o mistério da existência finita na sua busca temporal e multicultural do sentido. A reflexão começa a transformar-se em interpretação pois percebe-se que o pensar não surge apenas para que o homem possa dominar e utilizar o mundo a seu bel- prazer mas, pelo contrário, é suscitado pelo mistério da formação ética do existir, pela vida que é capaz de se elevar a uma nova ordem, o que obriga a reavaliar a clássica relação entre o particular e o universal. Esta só pode ser retomada a partir da noção de texto: tal foi a grande intuição de Dilthey que, no entanto, não soube nem pôde, no seu tempo, pensar convenientemente a ligação entre vida, linguagem e texto ${ }^{(3)}$.

Dilthey permite-nos no entanto perceber, indo é claro para além dele, como uma Hermenêutica Filosófica, mesmo que tome a forma metodológica,

(3) Cf., quanto a este assunto P. Ricoeur, "Qu'est-ce qu'un texte ?» in idem, Du texte à l'action. Essais d’herméneutique, II. Paris, Seuil, 1986, pp. 137-160. 
tem como problema central a existência relacional, as suas dúvidas, as suas diferentes formas de comunicação e de significação. Ela propõe-se como uma nova fenomenologia do real que parte de significações, onde se expressa um vivido, e procura debruçar-se sobre o que cimenta as relações humanas: a memória ou a linguagem na sua função formadora de identidades, criadora de ideários comuns e esquemas de conduta. São, pois, as condições pós-modernas do pensar, nomeadamente, aquelas que permitem conceber uma outra relação particular-universal, que se reflectem numa Hermenêutica Filosófica, quando a crise da evidência e a secura do modelo tecnocientífico da razão impõem o reconhecimento de outras modalidades de ser e habitar o mundo.

Categorias como as de tradição, obra de arte e norma perfilam-se então como modelos absolutamente nucleares deste tipo de pensamento, para o qual a relação entre particular e universal não pode seguir um método apofântico de certificação mas vai buscar à prática clássica da exegese o ideal de uma outra forma de mediação. Ao nível hermenêutico, vimos já, a mediação não visa o domínio das relações causais que permitem a eficiência sobre o mundo, por meio de um know-how teorético-técnico, mas aquilo que pode fomentar a solidariedade, a sensibilidade e a imaginação, oferecendo por esse facto novas possibilidades à praxis social do ser concreto. Esta não é a aplicação cega dos conhecimentos teóricos da ciência às virtualidades do nosso poder agir, mas pressupõe a percepção de uma relação de meios e fins e o exercício de uma capacidade de escolha(4). A Hermenêutica visa a formação desta capacidade, perguntando pela função da tradição histórica no desenvolvimento do mundo vivido do homem, ser social e não gregário. Ela sabe que este mundo tem na sua raiz a comunidade de uma interrogação, hierarquizada segundo épocas e horizontes, que se diz por meio de textos, mitos, contos e metáforas. Então a relação entre textos fundadores, que se compreendem pela sua relação às situações particulares da vida, e o mundo

(4) H.-G. Gadamer, Lob der Theorie. Reden und Aufsätze, Frankfurt, Suhrkamp, 1983, p. 82. 
da vida constitui o eixo determinante desta nova racionalidade, de cariz praxiológico, porque atenta ao efeito histórico do fenómeno humano da transmissão e ao concreto das sittuações existenciais, que reclamam balizas orientadoras para as suas escolhas.

A compreensão não é pois uma postura metodológica, que possamos adoptar, é algo que nós somos e devemos exercer, enquanto os únicos seres capazes de pensar a partir de uma transmissão e dotados de memória; ela é o modo de ser do Dasein, explica-nos já Heidegger, no parágrafo 31 de Ser e tempo ${ }^{(5)}$, definindo a sua textura pela ideia de possibilidade ou de capacidade. Nesta forma de conceber transparece um sentido dinâmico e praxístico - um projecto de existência - que exige a vigilância de uma explicitação ou apropriação que, por sua vez, sabe que parte de uma précompreensão e que tem como principal tarefa reconquistar o fenómeno essencial do ser aí, contra a sua dissimulação. A interpretação é agora o comportamento originário e constitutivo do Dasein perante o mundo e designa, antes de mais, o facto de este ser aquele ente que levanta de novo a questão do ser, depois de um longo esquecimento, traduzido pelo primado dos ideais gnoseológicos da ciência moderna. Estes reduzem o ser puros entes ou objectos situados diante de um sujeito que adquire, por sua vez, o estranho poder de os manipular.

A partir de Heidegger percebe-se finalmente que a questão hermenêutica não é na sua origem um problema de metodologia das ciências humanas, mas constitui o traço existencial do ser -aí(6), a natureza do seu próprio movimento vital(7). A hermenêutica deve devolver ao Dasein a sua dimensão essencial, a de vida que se faz cuidado ou compreensão pois é do cuidado do Dasein com o seu próprio ser que nasce o filosofar. Ela é uma interpretação da facticidade do ser-aí, "é a própria facticidade que se eleva

(5) M. Heidegger, Sein und Zeit, Tübingen, Max Niemeyer Verlag, 1979, pp. 142-148.

(6) H.-G. Gadamer, Gesammelte Werke II, Hermeneutik I. Wabrheit und Methode 2. II, Tübingen, Mohr,1986, p. 125.

(7) Idem, ibidem, p. 103. 
à interpretação"(8) uma vez que o ser que realmente somos nos distingue de todos os entes pela natureza semântica e ontologicamente significativa da sua praxis. O Dasein é o único ente a quem preocupa a questão do sentido e por esse mesmo facto, é tempo e cuidado, um sendo capaz de ser tocado, alimentado e modificado pelo poder universal da palavra em que outros já fizeram sentido. O que significa que nunca vive imerso na pura positividade dos factos, é tempo vivido e como tal surge sempre misturado em tradições, histórias e instituições, que fundam e suscitam o seu modo de ser relacional e comunitário.

É com Heidegger que a facticidade da vida humana se converte no principal tema da Hermenêutica, que deixa claramente o registo tradicional para designar o modo de ser do ente que resiste a toda a tentativa de uma compreensão transparente. A hermenêutica do Dasein, o interpelado na questão do ser, descobre que este é mundano e temporal, que habita o mundo de modo hermenêutico e preocupado( ${ }^{(9)}$, isto é, que é actividade e não representação, um projecto que se projecta para além de si confrontandose constantemente com a significação do passado e nomeadamente com a alteridade do futuro; que compreender é para o Dasein ser, e que esta compreensão, que tem a forma da acção preocupada e do cuidado, parte de uma pré-compreensão, é anterior a toda a dialéctica metodológica e a toda a redução da linguagem ao primado da transparência.

É a linguagem o lugar do misterioso encontro entre o ser e o homem, foi sempre ela que suscitou a hermenêutica, denominação que nos seus últimos escritos Heidegger abandona, deslocando-a do plano existencial para o da história do envio do ser. O problema hermenêutico resume-se agora à escuta e anúncio do ser, que nunca se explicita definitivamente e por isso permanece sempre uma diferença. A palavra assume então todo

(8) Idem, Gesammelte Werke 3. Neuere Philosophie I. Hegel-Husserl-Heidegger, Tübingen, Mohr, 1987, p. 422.

(9) Cf. M. Heidegger, Sein und Zeit, pp. 66-88. 
o seu relevo de abertura e instituição de mundos que anteriormente não existiam: ela diz a distância e o envio do ser.

H.- G. Gadamer, discípulo de Heidegger e autor da maior reflexão filosófica sobre a natureza da Hermenêutica ${ }^{(10)}$, retoma a problemática das ciências humanas a partir do efeito filosófico da obra de Heidegger, Interpretações fenomenológicas de Aristóteles(11), núcleo germinal de Ser e tempo; do seminário do filósofo sobre a ética do Estagirita(12); das importantes meditações de Ser e tempo sobre a temporalidade do Dasein e ainda da importância concedida pela última fase de M. Heidegger à problemática linguagem. Para Gadamer a hermenêutica é uma filosofia prática, na acepção aristotélica do termo(13), na medida em que o seu principal objectivo é promover para o Dasein os rituais da vida ética, aqueles que o império da ciência tornada técnica, pela via do método, obrigou a abandonar: «(...) desde os tempos mais remotos, até hoje, a Hermenêutica esboçou sempre a exigência de que a sua reflexão (...) sirva e promova de modo imediato a praxis (...)»(14). Enquanto filosofia prática, ela é uma de forma conhecimento, que nos recorda não ser este apenas algo que se consegue por meio da distância crítica e metódica, que a Modernidade nos ensinou a praticar, mas brota do cuidado da existência consigo mesma, cuidado que não se reduz, como bem o revelou Heidegger, à vontade humana de poder.

Segundo Gadamer, o ideal metódico de certificação da ciência moderna permite, sem sombra de dúvida, o desenvolvimento da tecnologia e a exploração do real, em termos de utilidade, mas falha completamente o modo como a verdade tem lugar nas humanidades. Estas compreendem-se muito

(10) Cf. H.-G. Gadamer, Gesammelte Werke 1-10 Bande.

(11) Cf., Idem, Philosophische Lehrjahre. Eine Rückschau, Frankfurt, Klosterman, 1977, p. 212.

(12) Cf., J. Grondin, Introduction à Hans-Georg Gadamer, Paris, ed du Cerf, 1992, pp. 15-17.

(13) H.-G. Gadamer, Vernunft im Zeitalter der Wissenschaft, Frankfurt, Suhrkamp, 1980, pp. 78-109.

(14) Idem, ibidem, p. 84: "Ganz deutlich hat die Hermeneutik von den ältesten Zeiten bis zum heutige Tage den Anspruch erhoben, dass ihre Reflexion (....) für die Praxis unmittelbar dienlich und förderlich sei (...)». 
melhor a partir da tradição humanista da Bildung, seguida por Herder e Hegel, a que Verdade e Método ${ }^{(15)}$ dedica grande importância ao longo de toda a sua primeira parte. Esta memória constitui a grande herança que o filósofo quer reabilitar para o carácter originário e existencial da compreensão, que considera fundamentalmente ocupada com a formação do Dasein. Isto é, com a capacidade que este tem de ultrapassar as suas perspectivas estreitas e singulares, em ordem a poder abrir-se a novos horizontes mais universais e a poder agir a partir de ideários que efectivamente o ligam aos outros homens. Por isso nos diz que a hermenêutica tem tudo a ver com o tipo de experiências de sentido que fazemos quando, face ao outro, percebemos que podemos não ter razão, quando nos deixamos tocar pela palavra dos outros, pelo encontro pleno de significado com a obra de $\operatorname{arte}^{(16)}$ ou com determinados valores transmitidos pela tradição(17). A hermenêutica faz, nomeadamente, sentido quando sabemos apropriar ou traduzir as referências significativas destes encontros para a nossa situação concreta. A própria fusão de horizontes, que o filósofo caracteriza como principal tarefa hermenêutica, implica justamente que: a) a interpretação parte, dado que é finita, de uma antecipação da perfeição(18) e nunca de uma atitude de dúvida ou suspeita; b) que esta antecipação, expressa por meio de pressupostos, prepara o intérprete para a escuta da palavra do outro, que poder dizer-lhe algo de novo(19) e assim consolidar ou não o que era apenas uma pressuposição. Ela prepara-o ainda para o diálogo com o texto que lhe transmite valores, usos, normas e testemunhos de decisões. O que lhe proporciona afinal uma forma de conhecimento, marcado pelo questionamento e tradução para a sua situação, discernimento a que Gadamer

(15) Idem, Gesammelte Werke I, Hermeneutik I.Wahrheit und Methode 1. p. 9-47.

(16) Idem, ibidem, p. 2.

(17) Idem, ibidem, p. 3.

(18) Idem, Le problème de la conscience historique, Paris, Nauwelaerts, p. 84.

(19) Idem, Préface, pp. VI-VII, in Jean Grondin, L'universalité de l'herméneutique, Paris, Puf, 1993: «L'herméneutique ne vise pas l'objectivation, mais l'écoute mutuelle, savoir prêter l'oreille, par exemple à quelqu'un qui sait raconter quelque chose». 
chama prático, na linha de Aristóteles porque pertence à experiência que nos dá figura na praxis diária das nossas vidas.

Experiência não significa aqui, claro está, a experimentação científica de laboratório, mas algo que deve entender-se como um movimento de formação pessoal que se processa naturalmente entre um estar inserido em situações e tradições - elas constituem o primeiro horizonte da nossa compreensão de mundo (pré-compreensão) - e a exigência ética de clarificação do repto lançado pela palavra do outro. Acentuar a tradição como a verdadeira raiz da possibilidade de diálogo e da formação, não significa pois favorecêla contra o conhecimento crítico, mas apenas lembrar ao ser finito a sua passividade: ele parte sempre de pressupostos, logo nunca pode justificar as fontes e fundamentos das suas crenças.

Chegamos demasiado tarde para fundamentar pelos nossos próprios meios a simbólica que guia o nosso agir; estamos pelo contrário já sempre misturados em histórias, valores, leis, que orientam a nossa acção no mundo. Partimos das figurações simbólicas do passado, de costumes e tradições que devem, por sua vez, ser ampliadas e discutidas em cada situação concreta da acção, quer isto dizer, compreendidas de modo novo e diferente.

É esta a verdadeira condição do conhecimento prático de ordem ética e moral: ele chega-nos a partir da tradição, nunca existe sem pressupostos, mas tem que ser recriado na situação que nos concerne. Compreender não é aqui dominar a situação(20), a partir de categorias prévias, mas saber-se afectado pelo assunto em questão e actualizá-lo em determinada situação. A aplicação é sempre uma exigência ética, uma explicitação interessada e não neutra do assunto veiculado pelo texto; sublinha nele determinados contornos, é uma tarefa eminentemente prática. Para Gadamer é ela o núcleo fundamental da problemática hermenêutica, logo é urgente reconquistar, para

(20) Idem, Gesammelte Werke I, Hermeneutik. I. Wahrheit und Methode 1. Tübingen, Mohr, 1986, p. 316. 
além da hermenêutica romântica e histórica, a unidade de compreensão, interpretação e aplicação(21).

E de acordo com esta forma de compreensão, que é em si mesma uma aplicação - aquela que Gadamer defende como verdadeiro núcleo de uma hermenêutica, na base dos exemplos das hermenêuticas jurídica e teológica -, não é legítimo dizer que primeiro compreendemos e depois aplicamos: pelo contrário, a própria compreensão é aplicação, isto é, uma forma de estar ao serviço de aquilo que deve ser revelado(22). Sem esta realização bic et nunc do sentido do texto, que me interpela, nem sequer há compreensão. O texto, seja ele a lei ou a mensagem da salvação, deve ser entendido de acordo com as suas pretensões formadoras, isto é, deve ser compreendido em cada momento e em cada situação concreta de uma maneira nova e diferente(23). Por isso é que há uma tarefa hermenêutica. O grande problema da hermenêutica consiste então em determinar o tipo de racionalidade a que corresponde esta forma de aplicação de um universal a uma situação particular, e que tipo de universal é este.

Tendo consciência do carácter provocador deste conceito de aplicação, Gadamer recorre à racionalidade aristotélica da fronesis, a sabedoria prática, prudente e mediadora, lembrando a semelhança entre a hermenêutica e a ética de Aristóteles: «A ética aristotélica adquire para nós uma importância particular (...). É claro que em Aristóteles não se trata do problema hermenêutico (...), mas da medida exacta que deve desempenhar a razão no agir moral. Mas é precisamente isto o que aqui nos interessa, trata-se aqui de uma razão e de um saber que não são separáveis de um ser, tal como este chegou a ser, mas são determinadas por este e determinantes para ele».(24)

(21) Idem, ibidem, p. 313.

(22) Idem, ibidem, p. 316.

(23) Idem, ibidem, p. 314.

(24) Idem, Gesammelte Werke I Hermeneutik I. Wabrheit und Methode 1. p. 317: "Damit gewinnt die aristotelische Ethik für uns eine besondere Bedeutung(...). Gewiss geht es bei Aristoteles nicht um das hermeneutische Problem (...), sondern um die richtige Bemessung der Rolle, die die Vernunft im sittlichen Handeln zu spielen hat. Aber eben dies ist es, was uns interessiert, 
A fronesis ou prudência, era para Aristóteles, sophia, o eixo crucial da ética e era para os gregos um aspecto fundamental da filosofia. O Estagirita define, aliás o papel da fronesis como a capacidade de aplicar, ou recriar, de forma justa, a regra em cada caso, que por sua vez se configura a partir dela. E para caracterizar esta tarefa na sua peculiaridade e importância referese a três profissões eminentemente práticas e especialmente necessitadas da prudência: a do político a do juíz e a do médico. Vejamos: tal como o bom médico não é apenas aquele que conhece teorias sobre a doença do doente, mas aquele que o cura precisando, muitas vezes, para atender às circunstâncias do doente, de se distanciar dos manuais e das técnicas; tal como o juíz e o político precisam, como o médico, de partir de um saber e de uma hermenêutica da experiência prática para poderem tomar decisões, também aquele que possui a fronesis sabe o que lhe é útil e não apenas «o que é raro e divino e, no entanto, inútil à maneira de viver do homem» $(25)$.

A hermenêutica, tal como a ética aristotélica, é uma filosofia prática que não preconiza o ideal da sabedoria distante mas, ao contrário, desperta a consciência para o que lhe corresponde, como característica própria, a phroairesis, quer esta seja entendida como a formação das atitudes humanas básicas do tipo de preferir, que tem o carácter da areté, quer seja como a inteligência da reflexão e da procura de conselho que dirige todo o agir»(26). A hermenêutica procura simultaneamente desenvolver a capacidade de escolha e a consciência do elemento comum que a todos vincula(27), ensinando-nos a acolher o outro e a dialogar com ele, em ordem à construção de um horizonte partilhado de convenções e valores que permitam um verdadeiro habitar o mundo.

dass es sich da um Vernunft und um Wissen handelt, die nicht von einem abgewwordenen Sein abgelöst sind, sondern von diesemher bestimmt und für dieses bestimmend sind».

(25) Idem, Gesammelte Werke, 5. Griechiche Philosophie I. Tubingen, Mohr, 1985, p. 240.

(26) Idem, Hermeneutik als praktische philosophie, in idem, Vernunft im Zeitalter der Wissenschaft, p. 83.

(27) Idem, Gesammelte Werke II,Hermeneutik I. Wabrheit und Methode 2, p. 317. 
No seu texto "A Hermenêutica como filosofia prática»(28), Gadamer lembranos mesmo que a hermenêutica começou por ser uma arte ao lado daquelas que permitiam a convivência humana, tais como a Gramática, a Retórica e a Dialéctica: como a Retórica, ela indicava uma capacidade natural do homem 193 e significava a aptidão deste para as relações plenamente significativas com os outros homens ${ }^{(29)}$. Enquanto arte, ela era um elemento prático da actividade de compreender e de interpretar, e Gadamer refere ainda que a expressão arte (Kunstlehre) tem a sua raiz na própria tradição aristotélica que hoje se perdeu e na qual existia uma filosofia prática (sive politica) que continuou viva até aos finais do séc. XVIII. (30) Ora esta tradição formava os quadros sistemáticos de todas as artes, na medida em que todas elas estavam ao serviço da polis.

A própria expressão aristotélica filosofia prática, lembra-nos o filósofo, refere tanto a filosofia como a ciência, mas não o tipo de ciência que para os gregos era o modelo do conhecimento teorético, isto é a matemática (31). Prática era então todo aquele tipo de ciência que contradizia a filosofia puramente teorética, a qual envolvia a física, o saber da natureza, a matemática e a teologia (ciência primeira ou metafísica). A filosofia prática partia de um pressuposto que se perdeu com a Modernidade: uma vez que o homem é um ser político e não um cogito soberano, a ciência política era o nível mais elevado da filosofia. Esta filosofia prática não implicava qualquer tipo de oposição à ciência; a própria oposição à teoria, que é clara na classificação aristotélica das ciências, não é aqui determinante, como o prova a frase de Aristóteles, segundo a qual chamamos activo em grande medida àqueles que se determinam através da sua produção intelectual(32). Quer dizer, a própria teoria, como fim em si, e não como saber especializado,

\footnotetext{
(28) Idem, Hermeneutik als praktische philosophie, pp. 78-129.

(29) Idem, ibidem, p. 85.

(30) Idem, ibidem, p. 78.

(31) Idem, ibidem, p. 79.

(32) Idem, ibidem, p. 80.
} 
era para o filósofo grego uma praxis de vida, representava um traço basilar do humano: a capacidade de se distanciar de si mesmo(33).

Claro que todo este horizonte é para nós hoje muito estranho, uma vez que desde a Modernidade o significado da praxis refere a aplicação do saber útil, com tudo o que esta aplicação tem de massificação, de acomodação e mesmo de irresponsabilidade. Mas e é bom não esquecê-lo: o campo conceptual originário que determina a palavra e o conceito de praxis nada tem a ver com uma aplicação da ciência; diz pelo contrário respeito aos modos de comportamento dos seres vivos, na sua mais ampla generalidade. A praxis, enquanto é a vitalidade ou a qualidade do ser vivo, situa-se entre a actividade e o estar situado, significa a realização vital (energeia) do ser vivo em geral, ao qual corresponde um modo de vida. Ora, o modo de vida do homem é distinto do dos animais pela cidadania, que implica a regra universal e a froairesis, isto é, a capacidade de distanciamento, e a de escolha e execução.

Além disso, lembra-nos Gadamer, de acordo com Aristóteles, não é face à teoria que a praxis delimita os seus contornos mas, pelo contrário, diante do fabricar ${ }^{(34)}$ : «A filosofia prática determina-se através da diferença que existe entre o saber prático, daquele que livremente escolhe, e o saber aprendido do especialista, a que Aristóteles chama techné»(35). Com efeito, a praxis nada tem a ver com as artes de oficina, os saberes pragmáticos ou úteis, que se podem aprender e esquecer ou com as habilidades, por mais que estas sejam essenciais à vida em comunidade. Diz, pelo contrário, respeito àquilo que cabe a cada um enquanto cidadão e àquilo que forma a sua aretê; ela traz à consciência a maior distinção humana, poder submeter-se a regras e ser capacidade de escolha.

Nada é pois mais estranho à praxis do que a eficiência de uma eficácia cuja efectividade é apreciada pela sua utilidade. Poder escolher, poder agir

(33) Idem, Lob der Theorie, p. 83.

(34) Idem, ibidem, pp. 82-83.

(35) Idem, ibidem, p. 82. 
e ser imputável, eis as grandes linhas da praxis, que pressupõe a habitação das grandes narrativas, dos grandes mitos, dos rituais e ordenações (ethos), que fomentam a coesão social e política em que radica a responsabilidade e a solidariedade do viver em comum.

A ciência prática não é então nem uma ciência teorética, ao género da matemática, nem um saber útil ou especializado no sentido da poiesis. No entanto, ela é ciência(36): um saber universal, sempre sob condições. Com efeito, baseado numa pertença a costumes, a normas e a tradições, que constituem a rede simbólica originária do agir ético e cidadão, este tipo de conhecimento implica sempre uma mediação muito particular entre o desejo e a razão e ainda um entendimento com a situação na qual a norma deve ser recriada em acto.

A praxis pressupõe pois uma racionalidade singular: tal como a techné, parte de uma forma de sabedoria que orienta o agir, mas trata-se num e noutro caso de saberes muito diferentes. O saber da techné é instrumental, é uma forma de saber tirar proveito da natureza, um saber que primeiro se aprende e depois se aplica automaticamente. É um saber para poder. Ora o elemento fundamental do saber prático é, em Aristóteles, o desejo e a organização deste numa atitude firme, a formação da virtude ou, por outras palavras, o desejo natural acordado, confirmado e corrigido pela educação e pelo hábito, que dele fazem uma disposição estável. Mas atenção, não basta dizer que a virtude deve ter sido exercida e formada pela educação. É necessário precisar: por uma boa educação.

Praxis e techné, convenhamos, têm em comum a necessidade de uma forma conhecimento que as guie. No entanto, lembra-nos Gadamer, o saber dos artesãos não é, já desde o tempo de Sócrates, o saber que faz o homem enquanto cidadão(37). Praxis e techné implicam as duas uma forma de aplicação do saber à situação concreta, mas o que é facto é que a aplicação

(36) Idem, ibidem, p. 83.

(37) Idem, Gesammelte Werke I, Hermeneutik I.Wabrheit und Methode 1. p. 320. 
é nos dois casos totalmente diferente. Vejamos então como Gadamer nos descreve esta diferença: o que sabe produzir algo, sabe-o para si e irá fazê-lo do mesmo modo, sempre que se surjam as possibilidades de o fazer. Ora, aquele que deve tomar decisões morais também aprendeu algo; por educação e procedência está determinado de tal modo que sabe em geral o que é correcto. Mas a tarefa da decisão moral é a de acertar com o que é adequado numa situação específica, isto é, a de ver o que nela é correcto e possível de fazer, o que exige uma hermenêutica da situação.

Concluindo: a aplicação hermenêutica, tal como Gadamer a pensa, na linha da ética aristotélica, pressupõe a praxis como a recriação em acto do universal pré-compreendido, um universal que não é de modo nenhum de ordem técnica ou lógica. É, pelo contrário, simbólico, um esquema de acção que possui margens pouco claras, tal como acontece com o texto ou com a lei. Estes estão sempre referidos à exigência imperiosa da sua respectiva aplicação na situação concreta da praxis que exige decisão.

Pensar a praxis - a grande tarefa da hermenêutica - exige pois que se reconheça, em primeiro lugar, a simbólica do agir, quer dizer, o conjunto dos rituais e regras que permitem a convivência e ainda o modo como eles se transmitem e re-interpretam de forma não automática. Em segundo lugar, que se reflicta sobre a capacidade humana de preferência e iniciativa, a froairesis que possibilita passar à decisão. A praxis ética tem uma estrutura hermenêutica, porque parte de um saber prévio que necessita de ser explicitado e apropriado por meio de uma aplicação que, sendo escolha e interpretação, exige o diálogo.

Tal é a importância da reflexão gadameriana: a praxis de cunho ético e político, aquela que reclama a decisão, tem uma estrutura hermenêutica que deve ser pensada e reabilitada contra a praxis automatizada dos nossos dias. Esta última é comandada pelo agir técnico e pelo primado do homo laborans. Interessante será então lembrar, recorrendo de novo à interpretação gadameriana de Aristóteles, o que distingue o saber ético, modelo da 
hermenêutica, do saber técnico, modelo do agir especializado e eficiente, aquele que comanda o labor das sociedades de hoje.

Em primeiro lugar, lembra-nos, Aristóteles, uma técnica aprende-se e pode ser esquecida. Ora, o saber ético nem se aprende nem se esquece, como o do profissional, (que pode recusá-lo, perder jeito(38) e escolher outro). Porquê? Porque o sujeito ético caracteriza-se pelo facto de estar já irremediavelmente lançado em situação de agir, isto é: está já sempre obrigado a possuir um saber ético e a aplicá-lo segundo as exigências da sua situação concreta(39). O saber ético não se aplica de maneira idêntica à do saber técnico, dado que ele não é propriedade do sujeito ético, como acontece com o técnico. Com efeito, se é verdade que a imagem que todo o homem forma do que seja o justo, o injusto, a coragem e a solidariedade, é constituída por ideias directrizes (aprendidas sobretudo na literatura), há uma diferença radical entre estas ideias e aquelas que o artesão aplica. É que o que é justo é totalmente relativo à situação ética em que nos encontramos; não se pode, de facto, descrever-se de modo abstracto que acções são justas e quais as que não são. Mesmo que se diga que o que é recto e justo se define por meio de leis ou regras de comportamento, não codificadas, mas válidas para todos, é apenas na aplicação da norma à situação concreta que os contornos da norma se definem. E quando aplicamos uma lei, pode acontecer que sejamos obrigados a atenuar, por via das características da situação, o rigor dessa mesma lei. Ora, atenuar o rigor da norma, não é não aplicar o direito que a lei exprime, nem tão pouco permitir um laxismo ilegítimo ${ }^{(40)}$. Atenuar o rigor de uma lei não significa renunciar-lhe, mas saber que sem essa interpretação não haveria propriamente justiça. O mesmo não acontece com a techné do artesão; é que o molde é completo e a lei sempre insuficiente e esquemática: "não em razão de um defeito intrínseco, mas porque o mundo, enquanto lugar

(38) Idem, Le problème de la conscience historique, p. 56.

(39) Idem, ibidem.

(40) Idem, ibidem, p. 58. 
das nossas acções, é sempre imperfeito por relação à ordem ideal visada pelas leis». (41)

Em segundo lugar, enquanto a actividade técnica tem antecipadamente consciência dos meios justos, que realizam um determinado fim, na phronesis os próprios fins nunca se dão como estando perfeitamente determinados e os meios devem ser sempre pesados de novo pelo sujeito. O domínio ético é aquele "onde o saber técnico cede o lugar à deliberação e à reflexão»(42); O saber ético apenas se cumpre na situação concreta, "bic et nunc». Chamamos saber ético (...) ao que une, de uma forma original, os nossos conhecimentos dos fins e dos meios e se opõe precisamente desse ponto de vista, a um saber puramente técnico. Deixa pois de ter sentido distinguir saber e experiência, pois o saber ético é em si mesmo já uma experiência(43).

Em terceiro lugar, o saber ético pressupõe uma forma de consciência de si absolutamente diferente daquele que transparece na técnica, na medida em implica um outro traço fundamental, a compreensão do outro ou sunesis: isto é a possibilidade de nos colocarmos na situação em que o outro deve agir. Também neste caso o saber não é geral, mas exige uma realização concreta, que supõe o laço comunitário que me permite viver em harmonia com o outro. Aliás, o facto de viver em harmonia com alguém não manifesta todo o seu alcance ético senão pelo fenómeno da "compreensão», que, nada tem a ver com o simples conhecimento técnico do psicólogo ou do expert, mas se concretiza no fenómeno do conselho moral, válido entre amigos. Só a pertença dos amigos a uma mesma causa justa permite o conselho e o discernimento da situação do outro, logo a tolerância ou indulgência que daí resultam. Aristóteles assinala, com efeito o carácter puramente virtuoso do saber ético e, para lhe dar ainda mais relevo, descreve a forma degenerada da fronesis que caracteriza o homem que, por meio da sua inteligência

(41) Idem, ibidem.

(42) Idem, ibidem: «Il s'ensuit qu'on caractérise le domaine éthique comme un domaine où le savoir technique cède la place à la délibération et la réflexion».

(43) Idem, ibidem, pp. 61-62. 
subtil, dá a volta a todas as situações para sua própria vantagem. A oposição deste à fronesis propriamente dita é evidente: «(...) este homem abusa do seu poder sem qualquer consideração ética. E não é por acaso que o nome deste homem que vence, não importa que situação, se traduz, precisamente por temível. Nada é mais assustador do que um génio organizado, e que não tem em conta o bem e o mal»(44).

Contra a possibilidade de domínio do mundo por esta forma puramente operatória da consciência humana, trabalha a hermenêutica filosófica, promovendo a consciência crítico dialógica e a responsabilidade da decisão.

(44) Idem, ibidem, p. 68. 


\section{Série}

\section{Documentos}

Imprensa da Universidade de Coimbra

Coimbra University Press

2007

- U

C • 